\title{
Refractory Malignant Germ Cell Tumor
}

National Cancer Institute

\section{Source}

National Cancer Institute. Refractory Malignant Germ Cell Tumor. NCI Thesaurus. Code C123739.

Malignant germ cell tumor resistant to treatment. 